\title{
HTGR Industrial Application Functional and Operational Requirements
}

August 2010

The INL is a

U.S. Department of Energy National Laboratory

operated by

Battelle Energy Alliance

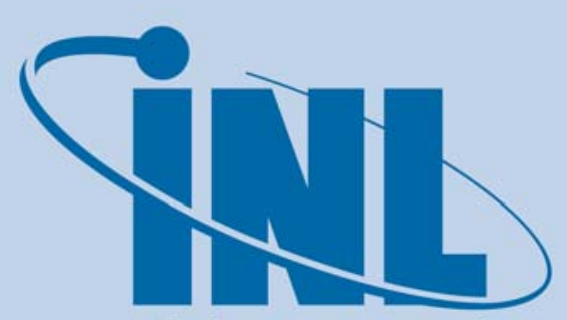

Idaho National Laboratory

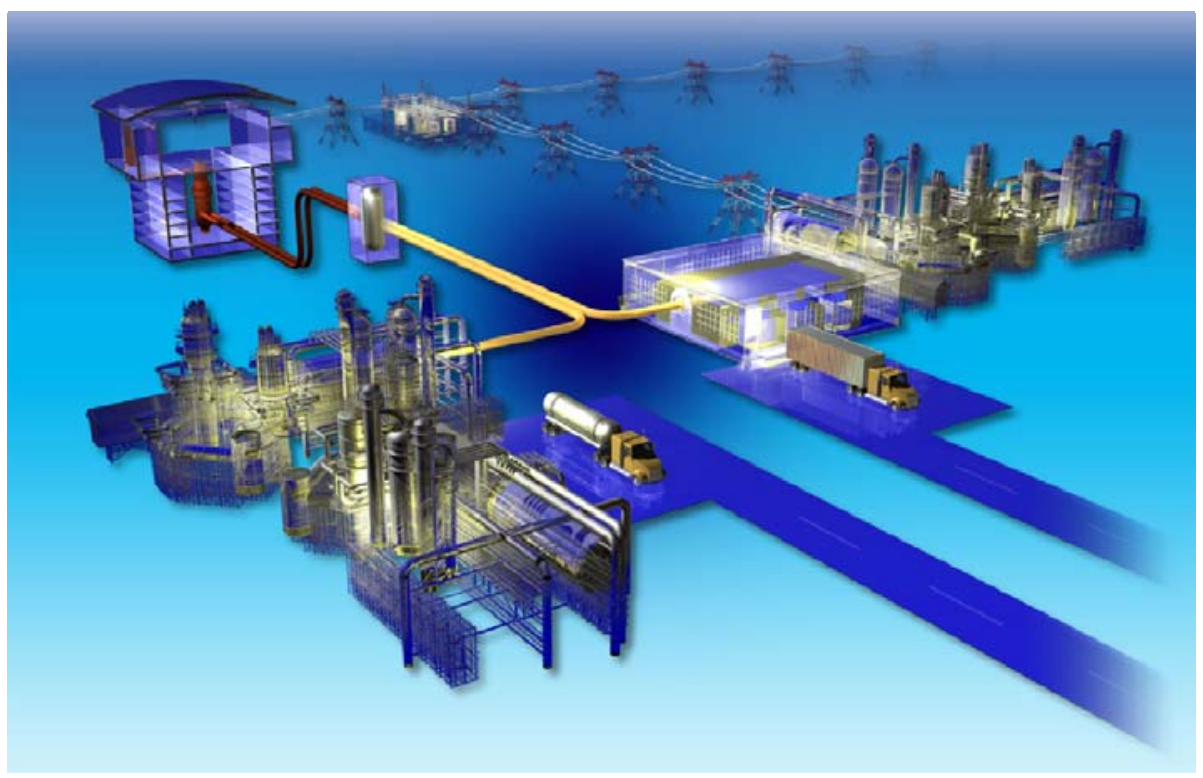




\section{DISCLAIMER}

This information was prepared as an account of work sponsored by an agency of the U.S. Government. Neither the U.S. Government nor any agency thereof, nor any of their employees, makes any warranty, expressed or implied, or assumes any legal liability or responsibility for the accuracy, completeness, or usefulness, of any information, apparatus, product, or process disclosed, or represents that its use would not infringe privately owned rights. References herein to any specific commercial product, process, or service by trade name, trade mark, manufacturer, or otherwise, does not necessarily constitute or imply its endorsement, recommendation, or favoring by the U.S. Government or any agency thereof. The views and opinions of authors expressed herein do not necessarily state or reflect those of the U.S. Government or any agency thereof. 


\section{HTGR Industrial Application Functional and Operational Requirements}

August 2010

Idaho National Laboratory

Next Generation Nuclear Plant Project

Idaho Falls, Idaho 83415

Prepared for the

U.S. Department of Energy

Office of Nuclear Energy

Under DOE Idaho Operations Office

Contract DE-AC07-05ID14517 

Next Generation Nuclear Plant Project

HTGR Industrial Application Functional and Operational Requirements

INL/EXT-10-19706

August 2010

Approved by:

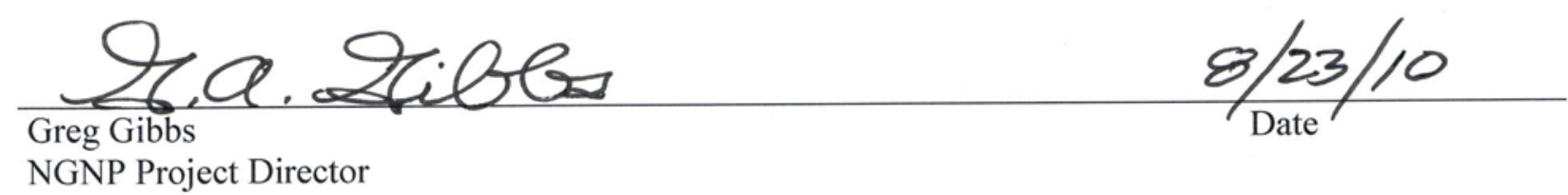





\begin{abstract}
This document specifies the functional and operational requirements to be used in the development of the conceptual design of a high temperature gascooled reactor (HTGR) based plant supplying energy to a typical industrial facility. These requirements were developed from collaboration with industry and HTGR suppliers over the preceding three years to identify the energy needs of industrial processes for which the HTGR technology is technically and economically viable. The functional and operational requirements specified herein are an effective representation of the industrial sector energy needs and an effective basis for developing a conceptual design of the plant that will serve the broadest range of industrial applications.
\end{abstract}




\section{CONTENTS}

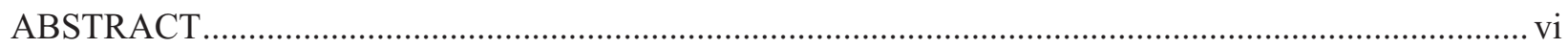

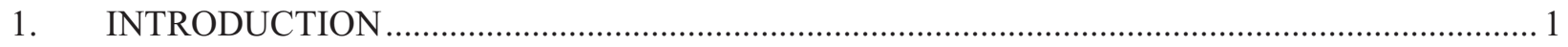

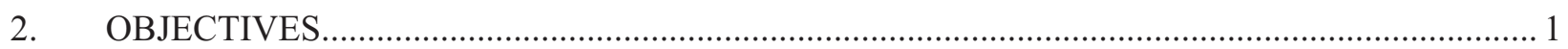

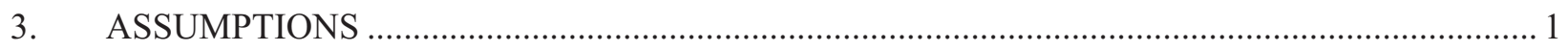

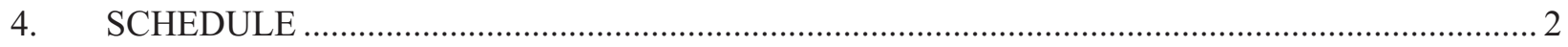

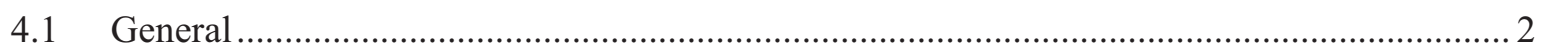

4.2 Plant Deployment Schedule \& Information Requirements ............................................. 2

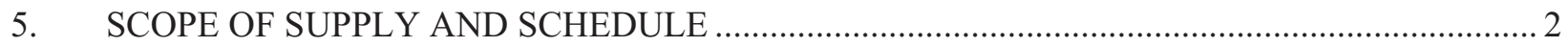

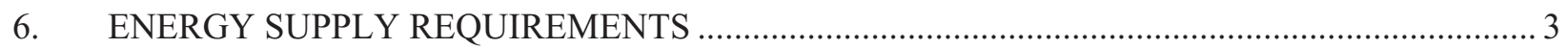

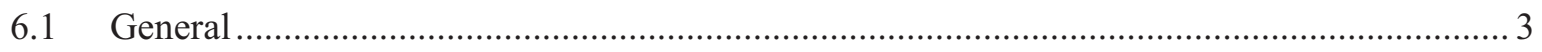

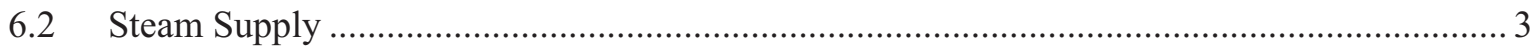

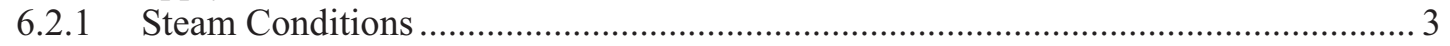

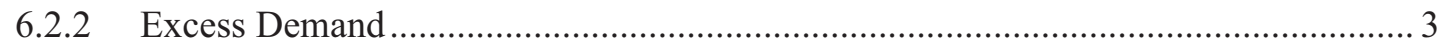

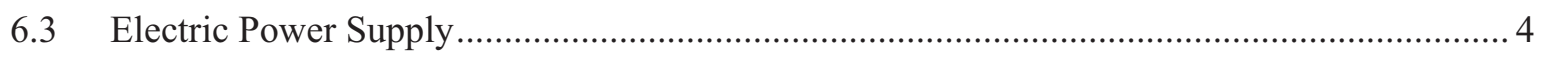

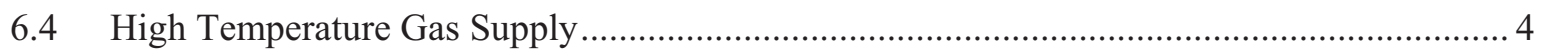

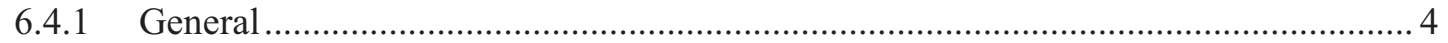

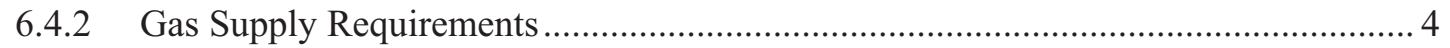

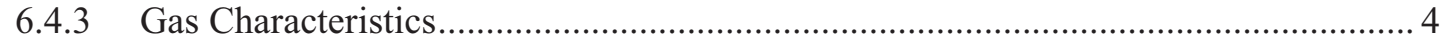

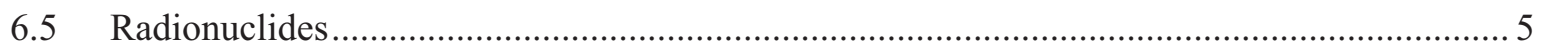

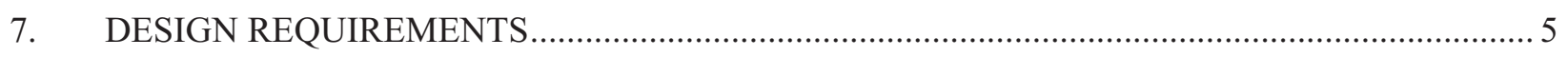

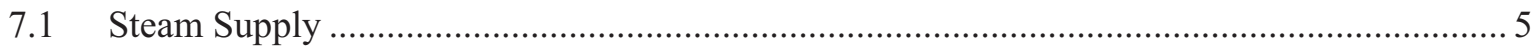

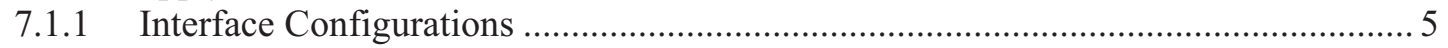

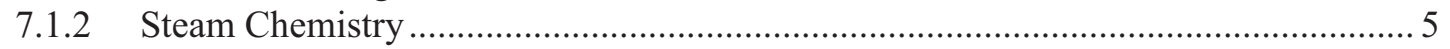

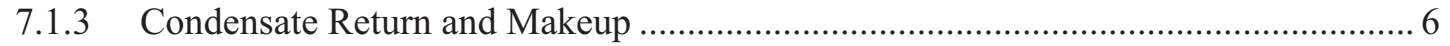

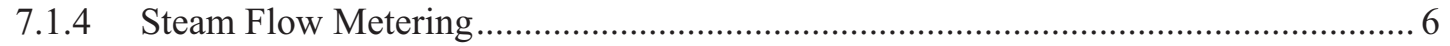

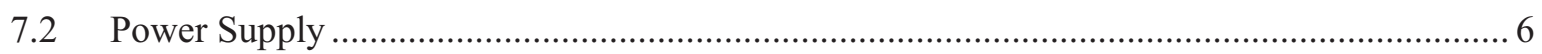

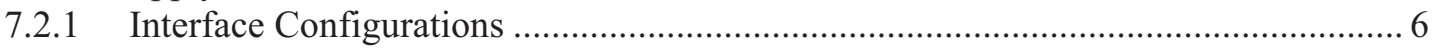

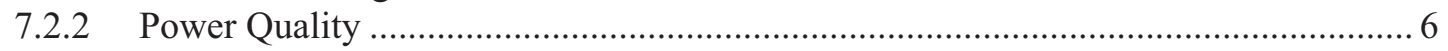

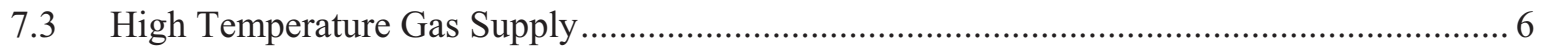

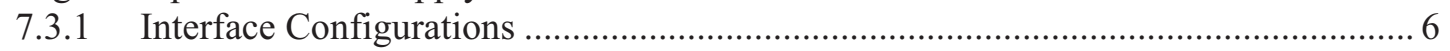

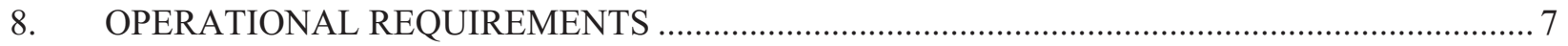

8.1 Normal and Emergency Demand Transients ............................................................. 7

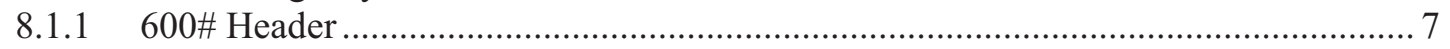

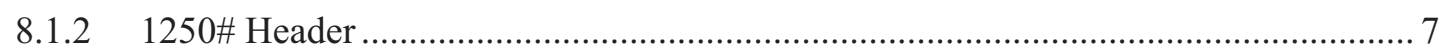

8.1.3 Electric Power ................................................................................ 7

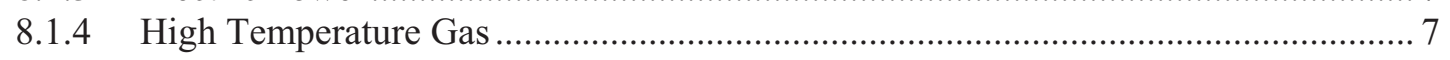

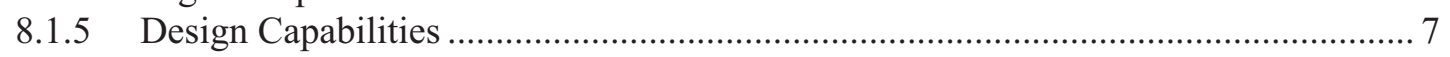

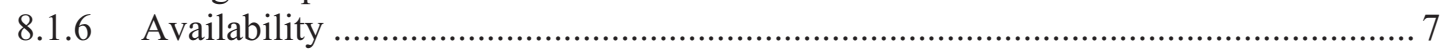




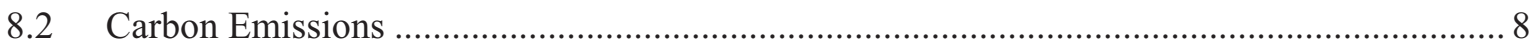




\section{HTGR Industrial Application Functional and Operational Requirements}

\section{INTRODUCTION}

This partial Technical Specification provides the functional and operational requirements for application of the high temperature gas-cooled reactor (HTGR) technology for supply of energy to a typical industrial facility. This plant can be comprised of multiple identical reactor modules or multiple reactor modules of differing ratings and configurations that fulfill the requirements herein. This partial specification forms the basis for the conceptual design of the HTGR plant to meet the specified functional and operational requirements for this energy supply. These functional and operational requirements shall be used to establish the HTGR plant total rating, ratings and number of individual modules, module and plant configurations, thermodynamic cycle, availability of the plant and other design factors.

These requirements represent a composite of information from discussions and detailed evaluations of energy needs jointly performed by INL and potential industrial end users. The specification will be updated as warranted as additional data is obtained.

For purposes of this specification, the following definitions apply:

End user The entity whose Facility is being supplied the required energy in the forms specified and on whose property the HTGR energy supply is located.

Purchaser The entity who purchases the energy from the Supplier, anticipated to occur via a long term energy purchase agreement.

Supplier The entity who owns the HTGR energy supply.

Operator The entity that is licensed to operate the HTGR energy supply.

Designer The entity that performs the design of the HTGR energy supply and supports the licensing activities by the Operator.

\section{OBJECTIVES}

The objective of this specification is to define an HTGR energy supply for supply of steam, electricity and high temperature gas that meets the requirements of the industrial facility for these products over a $[60]^{\mathrm{a}}$ year period.

\section{ASSUMPTIONS}

1. This specification does not include commercial issues.

2. The Purchaser will enter into a contract with the Supplier for long term supply of energy.

3. The HTGR plant (hereinafter referred to as the "Plant") will be operated by an entity other than the Purchaser.

4. The HTGR plant will be sited within the boundaries of or close to (within [1 mile]) the Facility.

5. The Purchaser will support the Supplier in providing and developing data and information required to obtain a combined license for construction and operation of the HTGR energy source.

a Items in brackets [ ] are representative or are to be determined; final values will be established during specification conformance. 
6. The HTGR Plant will be sited within or adjacent to the Facility controlled area. The selected site for the Plant will depend on site surveys conducted to support licensing of the Plant by the USNRC. The HTGR energy supply plant site will be a separate facility within or adjacent to the Facility controlled area but will be under the control of the Plant Operator as required by the USNRC for an operating nuclear plant.

\section{SCHEDULE}

\subsection{General}

The HTGR Energy supply shall be fully operational no later than January 1, 20xx (TBD). The Supplier shall provide a schedule for a phased deployment, including the increments of energy supplied in each phase and the accumulated capacity, in accordance with the requirements below, assuming a Greenfield application.

\subsection{Plant Deployment Schedule \& Information Requirements}

The Supplier shall provide a detailed schedule for deployment of the HTGR energy supply. This schedule shall include as a minimum the following:

1. Development of the licensing strategy including requirements and timing for developing and submitting licensing documentation and applications

2. Plant Design

3. Plant Licensing Reviews

4. For each increment of energy supply:
a. Procurement
b. Site mobilization
c. Construction
d. Cold and Hot Testing
e. Initial Operation
f. Full Operation.

The schedule shall be provided in [Primavera format at level 3].

\section{SCOPE OF SUPPLY AND SCHEDULE}

\section{General}

The HTGR plant will replace and augment existing power plants at the Facility that supply steam to the processes and electricity to support facility operation and substitute for the burning of gases in selected plant processes. The supply of steam and high temperature gas to the facility processes is the primary function of the HTGR energy supply systems and $100 \%$ availability is required. The electrical distribution system within the facility includes a cross-connection with the regional electrical grid. The facility power plants may dispatch electrical power to the grid or take power from the grid depending on the price of electricity from the grid and the cost of facility generation. Power is also taken from the grid to augment the facility power supplies if necessary to meet facility demand. The HTGR supply of steam and electricity will replace a portion of the facility power plant capacity as these plants are retired. The HTGR energy supply shall provide process heat in the form of high temperature gas to selected plant processes to offset the emissions of greenhouse gases attendant to the burning of natural gas and waste 
gases in these processes. The supply of process heat to these processes will be implemented in parallel with the supply of steam and electricity in accordance with the schedule provided by the Supplier as part of the requirements of this specification.

\section{ENERGY SUPPLY REQUIREMENTS}

\subsection{General}

The Supplier will supply steam to two existing headers in the Facility at nominal pressures of 1250\# and 600\#; electricity to the Facility electrical distribution system and high temperature gas to the Facility in accordance with the following requirements. For each item the maximum and average required rate of supply and annual total supply are provided over a typical year. The HTGR Plant shall have sufficient capacity to meet these demands at $100 \%$ availability. The Supplier schedule for deployment shall specify the percentage of demand of each component that will be supplied by each increment and the accumulative supply as each increment is deployed. The demands for steam, electricity and high temperature gas will vary within the ranges shown below. The HTGR plant shall be designed to accommodate variations as specified below. Any major anticipated changes in demand, (e.g., for facility turnarounds) will be scheduled by the Purchaser.

\subsection{Steam Supply}

\subsubsection{Steam Conditions}

The following table specifies the supply conditions at the Plant header, the maximum and average demand and the total yearly supply required for each steam supply. Rates of changes in demand are bounded by the transient requirements specified in following sections of this specification.

\begin{tabular}{|c|c|c|c|c|c|}
\hline Header & $\begin{array}{c}\text { Pressure, } \\
\text { psig }\end{array}$ & $\begin{array}{c}\text { Temperature, } \\
\text { DegF }\end{array}$ & $\begin{array}{c}\text { Maximum } \\
\text { Demand, } \\
\text { Klbs/hour }\end{array}$ & $\begin{array}{l}\text { Average } \\
\text { Demand, } \\
\text { Klbs/hour }\end{array}$ & $\begin{array}{l}\text { Total Annual } \\
\text { Demand, } \\
\text { MMlbs }\end{array}$ \\
\hline 1250\# & 1,300 & 840 & 500 & 350 & 3,066 \\
\hline $600 \#$ & 650 & 660 & 1,300 & 910 & 7,972 \\
\hline Total & & & 1,800 & 1,260 & 11,038 \\
\hline
\end{tabular}

\subsubsection{Excess Demand}

Purchaser may exercise the option of increasing the steam demand from either header by up to $10 \%$ above the peak demand specified above after providing 24 hours notice. Such increases shall not extend for more than 24 hours. 


\subsection{Electric Power Supply}

The following summarize the electrical power requirements

$\begin{array}{ll}\text { Maximum Demand, MWe } & 715 \\ \text { Average Demand, MWe } & 500 \\ \text { Annual Demand, MWh } & 4.38 \times 10^{6} \\ \text { Distribution Voltage, KV } & \begin{array}{l}135 \text { Facility } \\ \end{array} \\ & 350 \text { Regional Grid } \\ \text { Phases } & 3 \\ \text { Frequency, hz } & 60 \pm 0.25 \text { (when islanded) } \\ \text { Power Factor } & 0.90 \\ \text { (Additional data as required) } & \\ \text { Regional Grid Transformer, KVA } \quad[700,000]\end{array}$

\subsection{High Temperature Gas Supply}

\subsubsection{General}

1. The high temperature gas supply circuit shall be isolated from the HTGR primary helium circuit.

2. The working gas shall be compatible with the materials of construction in the gas circuit at all anticipated normal and abnormal operating conditions (e.g., He, He-N2, Air, Argon).

3. The working gas shall be compatible with standard circulator designs.

4. A means to remove corrosion products and foreign objects shall be positioned in the gas circuit prior to entering the circulator.

\subsubsection{Gas Supply Requirements}

The following are the high temperature gas supply requirements.

$\begin{array}{ll}\text { Maximum Load, KWt } & 280,000 \\ \text { Average Load, KWt } & 200,000 \\ \text { Annual Load, KWth } & 1.752 \times 10^{6} \\ \text { Gas Pressure at Header, psig } & 1000 \\ \text { Supply Temperature at Header, }{ }^{\circ} \mathrm{C} & 900 \\ \text { Return Temperature at Header, }{ }^{\circ} \mathrm{C} & 325\end{array}$

\subsubsection{Gas Characteristics}

$\begin{array}{ll}\text { Oxygen } & \text { [upper \& lower limits TBD }] \\ \text { Nitrogen } & <[\mathrm{TBD}] \mathrm{ppm} \\ \text { Moisture } & {[\text { upper \& lower dew point TBD] }} \\ \text { Hydrogen } & <[\mathrm{TBD}] \mathrm{ppm} \\ \text { Carbon Dioxide } & <[\mathrm{TBD}] \mathrm{ppm}\end{array}$

Designer shall provide suggested ranges for gas characteristics based on compatibility with HTGR energy supply design and materials of construction. 


\subsection{Radionuclides}

The steam and high temperature gas shall not contain any detectable radionuclides either transported from the primary helium circuit or activated from exposure to the primary circuit.

\section{DESIGN REQUIREMENTS}

\subsection{Steam Supply}

\subsubsection{Interface Configurations}

The Designer shall complete the tables in the following sections.

\section{Steam Supply}

\begin{tabular}{|l|c|l|l|l|l|}
\hline \multicolumn{1}{|c|}{ Header } & $\begin{array}{c}\text { Pipe } \\
\text { Diameter, } \\
\text { Inches }\end{array}$ & Schedule & Material & Insulation & Flange \\
\hline $1250 \#$ & & & & & \\
\hline $600 \#$ & & & & & \\
\hline
\end{tabular}

Over pressure protection shall be provided at the energy source.

\section{Condensate Return}

\begin{tabular}{|l|c|l|l|l|l|}
\hline \multicolumn{1}{|c|}{ Header } & $\begin{array}{c}\text { Pipe } \\
\text { Diameter, } \\
\text { Inches }\end{array}$ & Schedule & Material & Insulation & Flange \\
\hline $1250 \#$ & & & & & \\
\hline $600 \#$ & & & & & \\
\hline
\end{tabular}

\subsubsection{Steam Chemistry}

Steam supplied to the $600 \#$ and 1250 \# header shall meet the requirements of the ASME guideline "Consensus on Operating Practices for Control of Feedwater and Boiler Water Chemistry in Modern Industrial Boilers.",

b Note that in some applications additional requirements for steam purity may also be mandated depending on the steam use (e.g. turbine driven compressors, etc.) in order to avoid unacceptable risk to component integrity or voiding of OEM warranties. 


\subsubsection{Condensate Return and Makeup}

Makeup and condensate from the steam supplied to the $600 \#$ and the 1250 \# headers will be returned within the following specifications:

$\begin{array}{ll}\text { Percent returned } & 100 \% \text { including makeup }^{\mathrm{c}} \\ \mathrm{pH} & 6 \text { to } 9 \\ \text { Conductivity } & \leq 10 \text { micro Siemens } / \mathrm{cm} \\ \text { TOC } & <3 \mathrm{ppm} \\ \text { Oxygen } & <6 \mathrm{ppm} \text { Saturated } \\ \text { Pressure } & <15 \text { psig in storage tank } \\ \text { Temperature } & 70^{\circ} \mathrm{F}\end{array}$

The supplier shall provide any additional conditioning equipment required to meet the specification for feed water or makeup water to the Plant.

Condensate supply from Purchaser shall be metered by [TBD].

\subsubsection{Steam Flow Metering}

Mass flow will be pressure and temperature compensated

\subsection{Power Supply}

\subsubsection{Interface Configurations}

The Designer shall provide the configuration and design requirements for the electrical connection between the generator and low voltage taps on the facility distribution transformer and the regional grid transformer.

\subsubsection{Power Quality}

The frequency and other properties and characteristics, (e.g., phase voltage imbalance) shall be as required by the regional electricity supply utility for operation on its electrical system. Power factor correction will be provided by the Supplier. For conceptual design work, Designer shall use typical requirements for the US grid.

\subsection{High Temperature Gas Supply}

\subsubsection{Interface Configurations}

\begin{tabular}{|l|c|l|l|l|l|}
\hline \multicolumn{1}{|c|}{ Header } & $\begin{array}{c}\text { Pipe } \\
\text { Diameter, } \\
\text { Inches }\end{array}$ & Schedule & Material & Insulation & Flange \\
\hline Supply & & & & & \\
\hline Return & & & & & \\
\hline
\end{tabular}

c Makeup will be limited to the capacity of the Facility. Any required makeup in excess of the capacity of the Facility shall be provided by the Supplier. 


\section{OPERATIONAL REQUIREMENTS \\ 8.1 Normal and Emergency Demand Transients}

The HTGR Plant shall be capable of responding to the following process transients without interruption or degradation of supply:

\subsubsection{0\# Header}

$\begin{array}{ll}\text { Step Change } & \pm 10 \% \\ \text { Maximum rate of change } & 20 \% / \text { min decreasing } \\ 20 \% / \text { min increasing }\end{array}$

\subsubsection{0\# Header}

$\begin{array}{ll}\text { Step Change } & \pm 10 \% \\ \text { Maximum rate of change } & 20 \% / \text { min decreasing } \\ & 20 \% / \text { min increasing }\end{array}$

\subsubsection{Electric Power}

$\begin{array}{ll}\text { Step Change } & \pm 10 \% \\ \text { Maximum rate of change } & 10 \mathrm{MWe} / \mathrm{min} \text { decreasing } \\ & 10 \mathrm{MWe} / \mathrm{min} \text { increasing }\end{array}$

\subsubsection{High Temperature Gas}

$\begin{array}{ll}\text { Step Change } & \pm 10 \% \\ \text { Maximum rate of change } & 20 \% / \text { min decreasing } \\ & 20 \% / \text { min increasing }\end{array}$

\subsubsection{Design Capabilities}

1. Plant shall be capable of accepting a full load rejection from either steam, electrical or high temperature gas demand.

2. Plant shall be able to accept zero steam flow demand and/or zero power demand, and/or zero high temperature gas demand. If all demand is lost temporarily the HTGR plant shall remain capable of meeting demand as it is restored within a maximum time period to be supplied by the Designer.

3. Plant shall be capable of accommodating coincident average steam, electrical and high temperature gas demand.

4. Plant shall be capable of operating with zero condensate return from Purchaser for 2 full power days.

\subsubsection{Availability}

The average required supply of steam to the $1250 \#$ and $600 \#$ steam headers, high temperature gas to the gas headers and electrical power generation to the electrical interconnections shall be available 100\% of the time (24 hours a day, 7 days a week, 365 (366 in leap years) days per year with two modules out of service. 


\subsection{Carbon Emissions}

The energy requirements specified herein shall be achieved by the HTGR energy supply using solely nuclear heat. 